\title{
Morpholinecarbonyl-Rhodamine 110 Based Substrates for the Determination of Protease Activity with Accurate Kinetic Parameters
}

\author{
Tatyana G. Terentyeva, ${ }^{\dagger}$ Wim Van Rossom, ${ }^{\dagger}$ Mark Van der Auweraer, ${ }^{+}$Kerstin Blank, ${ }^{*,+,}{ }^{+}$and \\ Johan Hofkens ${ }^{\dagger}$ \\ ${ }^{\dagger}$ Department of Chemistry, Katholieke Universiteit Leuven, Celestijnenlaan 200F, 3001 Heverlee, Belgium \\ ${ }^{\ddagger}$ Department of Molecular Materials, Institute for Molecules and Materials, Radboud University Nijmegen, Heyendaalseweg 135, \\ 6525 AJ Nijmegen, The Netherlands \\ Supporting Information
}

ABSTRACT: Commonly used fluorogenic substrate analogues for the detection of protease activity contain two enzymecleavable bonds conjugated to the fluorophore. Enzymatic cleavage follows a two-step reaction with a monoamide intermediate. This intermediate shows fluorescence at the same wavelength as the final product complicating the kinetic analysis of fluorescence-based assays. Fluorogenic substrate analogues

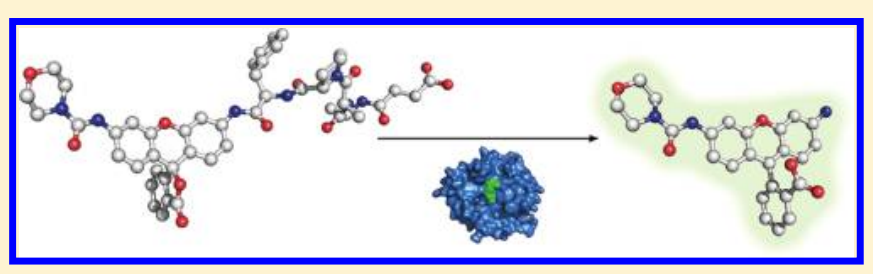
for $\alpha$-chymotrypsin with one cleavable peptide bond have been prepared from morpholinecarbonyl-Rhodamine 110 (MC-Rh110). A comparison of their kinetic properties with the corresponding (peptide) $)_{2}-\mathrm{Rh} 110$ derivatives revealed that these frequently used double-substituted substrate analogues yield only apparent $K_{\mathrm{m}}$ and $k_{\mathrm{cat}}$ values that are quite different from the kinetic parameters obtained from the monosubstituted MC-Rh110 based substrate analogues. Although both the monoamide intermediate and MCRh110 are monosubstituted Rhodamine 110 derivatives, they show different spectroscopic properties. The data from the spectroscopic analysis clearly show that these properties are directly related to the electron structure of the fluorophore and not to the previously proposed equilibrium between the lactone form and the open ionic form of the fluorophore. This knowledge about the determinants of the spectroscopic properties of monosubstituted Rhodamine 110 introduces a way for a more systematic development of new fluorogenic protease substrate analogues.

\section{INTRODUCTION}

Proteases and peptidases (EC 3.4) are enzymes that catalyze the hydrolysis of peptide bonds. They constitute approximately $2 \%$ of the human genome and are involved in many physiological processes such as cell-cycle progression, tissue remodeling, coagulation, wound healing, cell proliferation, and cell death, as well as the immune response. ${ }^{1}$ Their involvement in these biological processes makes proteases very important drug targets. Furthermore, proteases are important biocatalysts for a wide range of industrial applications. Understanding the enzymatic mechanism and the factors determining their substrate specificity is therefore of crucial importance for the characterization of their medical relevance as well as for obtaining optimized biocatalysts.

To assay enzyme activity and substrate specificity, fluorogenic probes are commonly used. ${ }^{2-4}$ The chemical modification of a fluorophore with one or two enzyme-cleavable bonds alters its photophysical properties and results in a nonfluorescent derivative. The fluorescence is recovered upon enzymatic cleavage. Peptide-based substrate analogues can further be designed based on photoinduced electron transfer ${ }^{5}$ or fluorescence resonance energy transfer. ${ }^{6,7}$ Fluorescence is often chosen as a detectable signal as it provides high sensitivity in vitro. Moreover, fluorescent probes also find widespread application in living cells and tissues where they provide high spatial and temporal resolution.
The choice of fluorophore is critical for the design of a good enzyme substrate analogue, and favorable fluorescent molecules have to meet several requirements: (i) high brightness to obtain high sensitivity, (ii) fluorescence excitation above $450 \mathrm{~nm}$ to reduce photodamage in biological molecules and to avoid interference with autofluorescence of biological samples, and (iii) no interference with the enzymatic reaction so that the kinetic parameters remain unaltered. ${ }^{8}$ Although frequently used, Coumarin-based substrate analogues have a low brightness and are excited below $450 \mathrm{~nm}$. Common fluorophores which possess the aforementioned properties and are often used for introducing an enzyme-cleavable bond are fluorescein, resorufin, and 7-hydroxy9H-(1,3-dichloro-9,9-dimethylacridin-2-one) (DDAO) for esterases, phosphoesterases, and glycosidases. Fluorophores used for proteases are Rhodamine 110 and cresyl violet. The latter, however, yields only substrate analogues with insufficient stability to autohydrolysis in aqueous solutions. ${ }^{9}$ Except for resorufin and DDAO, these substrate analogues contain two sites for conjugating the enzyme-cleavable group. ${ }^{10-12}$ Using the double-substituted pro-fluorescent derivatives for kinetic measurements complicates a

Received: February 25, 2011

Revised: July 13, 2011

Published: September 12, 2011 
quantitative analysis, since full fluorescence manifestation requires the cleavage of two bonds involving an intermediate with a different fluorescence intensity.

The difficulty of quantifying the kinetic constants of such a twostep reaction has been addressed in several studies, and solutions have been proposed to obtain the kinetic constants. ${ }^{13,14}$ These approaches, however, always require the detection of the intermediate concentration, which is often not possible in a fluorescence measurement due to the overlap of the excitation and emission spectra of the intermediate and the final product. Other assays to determine the intermediate concentration such as HPLC might not be considered feasible especially in highthroughput assays or measurements in cellular systems. As a consequence, efforts are being made to synthesize monosubstituted substrate analogues, and a number of examples exist utilizing Rhodamine 110 (Rh110).

The most obvious solution might be to attach only one peptide to the Rh1 10 core. Although this yields a stable molecule, the applicability of such a monoamide Rh110 derivative is limited by its fluorescence, which is approximately still $10 \%$ relative to Rh1 10. ${ }^{15}$ Hence, it is desirable to develop Rh110-based substrate analogues that have no intrinsic fluorescence while possessing only one enzyme cleavable bond. This has been achieved by modifying one of the amino groups with a nonhydrolyzable blocking group while attaching a peptide to the second amino group. Initially designed to increase cell permeability, a range of different blocking groups have been investigated, but they mostly yield dye molecules with a relative fluorescence intensity of only 5-15\% compared to Rh110. ${ }^{16-18}$ The best blocking group known to date, which preserves much of the high fluorescence of Rh110, introduces a urea functionality into Rh110. ${ }^{19}$ Originally designed by Wang et al., ${ }^{20}$ morpholinecarbonyl-Rh110 (MC$\mathrm{Rh} 110)$ is a promising candidate for developing sensitive monoamide substrate analogues.

Although Rh110 has been used for many years to synthesize substrate analogues for proteases, the properties of the monosubstituted derivatives have never been investigated systematically. Double-substitution of Rh110 yields a nonfluorescent lactone. Consequently, it has been proposed in several reports that the fluorescence of monosubstituted Rh110 is determined by an equilibrium between a nonfluorescent monosubstituted lactone form and an open zwitterionic fluorescent form of the molecule. It was further suggested that the electron withdrawing character of the substituent influences this equilibrium and therefore the fluorescence intensity of the respective derivative. $^{18,20}$

Using $\alpha$-chymotrypsin as the model system, we determined the enzyme kinetic parameters for different MC-Rh110 based substrate analogues and compared them with conventional bisamide Rh110 substrate analogues. Furthermore, we performed a systematic analysis of the photophysical properties of MC-Rh110 and monoamide Rh110 in order to understand why different substituents on one of the amino-groups of Rh110 yield derivatives with different fluorescence intensity.

\section{EXPERIMENTAL PROCEDURES}

Synthetic Approaches. Unless stated otherwise, reagents were obtained from Sigma-Aldrich or Acros. The substrate analogues were purified on a Waters 996 HPLC with a Waters 600 controller. Reversed-phase C18 columns (Alltech Previal or Phenomenex Luna, both $15 \mathrm{~cm}$ long with $2.1 \mathrm{~mm}$ diameter

\section{Chart 1}

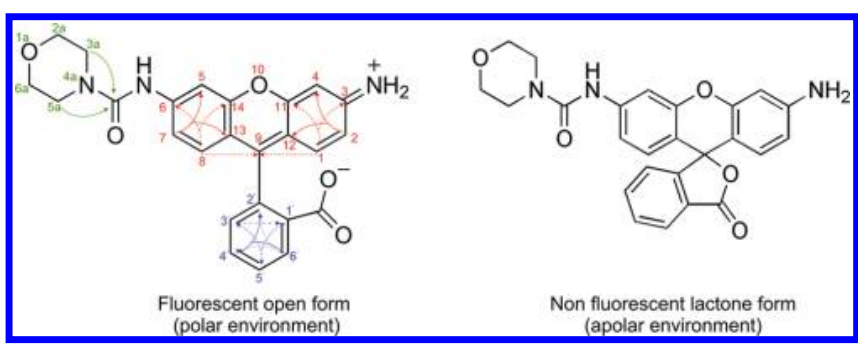

and $5 \mu \mathrm{m}$ particle size) were used. MPLC chromatography was performed using a Büchi Sepacore Flash apparatus. Mass spectra were run using Thermo Finnigan LCQ Advantage apparatus (ESI). NMR spectra were acquired on commercial instruments (Bruker Avance $300 \mathrm{MHz}$, Bruker AMX $400 \mathrm{MHz}$ or Bruker Avance II+ $600 \mathrm{MHz}$ with TXI probe or TCI CryoProbe) and chemical shifts $(\delta)$ are reported in parts per million (ppm) referenced to tetramethylsilane $\left({ }^{1} \mathrm{H}\right)$ or the internal (NMR) solvent signals $\left({ }^{13} \mathrm{C}\right)$. Rhodamine $110(99 \%$ pure, laser grade, Acros) was used for the synthesis of the substrate analogues.

(suc-AlaAlaProPhe) ${ }_{2}$-Rh110; (sucAAFP) ${ }_{2}-$ Rh110. The synthesis of (sucAAPF $)_{2}$-Rh110 was performed as described in the Supporting Information of De Cremer et $\mathrm{al}^{21}$ and verified by ESI and NMR spectrometry.

MC-Rh110. The synthesis of MC-Rh110 was based on the method described in the patent application by Diwu et al. ${ }^{22}$ Since the described purification procedure using a silica gel column did not yield pure product, the dye was purified with MPLC using a mixture of EtOAc/ $\mathrm{CHCl}_{3} / \mathrm{MeOH}$ (50:47.5:2.5). Yield: $25 \%$. MS (ESI+): $444\left(\mathrm{MH}^{+}\right) .{ }^{1} \mathrm{H}$ NMR $\left(600 \mathrm{MHz}, \mathrm{CDCl}_{3}\right): \delta(\mathrm{ppm})$ 7.99 (d, $\left.J=7.9 \mathrm{~Hz}, 1 \mathrm{H} ; \mathrm{H}-6^{\prime}\right), 7.65$ (t, $\left.J=7.5 \mathrm{~Hz}, 1 \mathrm{H} ; \mathrm{H}-5^{\prime}\right), 7.59$ $\left(\mathrm{t}, J=7.5 \mathrm{~Hz}, 1 \mathrm{H} ; \mathrm{H}-4^{\prime}\right), 7.50(\mathrm{~s}, 1 \mathrm{H} ; \mathrm{H}-5), 7.15$ (d, $J=7.6 \mathrm{~Hz}$, $\left.1 \mathrm{H} ; \mathrm{H}-3^{\prime}\right), 6.83$ (d, J=6.8 Hz, $\left.1 \mathrm{H} ; \mathrm{H}-7\right), 6.63$ (d, J = 8.6 Hz, $1 \mathrm{H}$; $\mathrm{H}-8$ ), 6.53 (d, J=8.3 Hz, 1H; H-1), 6.51 (s, 2H; H-4), 6.34 (d, J= $6.8 \mathrm{~Hz}, 1 \mathrm{H} ; \mathrm{H}-2), 3.90\left(\mathrm{~s}_{\mathrm{b}}, 2 \mathrm{H} ; \mathrm{NH}_{2}\right), 3.74(\mathrm{t}, J=4.7 \mathrm{~Hz}, 4 \mathrm{H}$; $\mathrm{H}-2 \mathrm{a}, 6 \mathrm{a}), 3.49$ (t, $J=4.7 \mathrm{~Hz}, 4 \mathrm{H} ; \mathrm{H}-3 \mathrm{a}, 5 \mathrm{a}) .{ }^{13} \mathrm{C}$ NMR $(125$ $\mathrm{MHz} \mathrm{CDCl}_{3}$ ): $\delta(\mathrm{ppm}) 169.8$ (C; COO), 154.7 (C; CO), 153.4 (C; C-6), 152.8 (C; C-11), 152.1 (C; C-14), 149.0 (C; C-3), 141.0 (C; C-2' ), 135.1 (CH; C-4'), $129.7(\mathrm{CH}$; C-1), $129.2(\mathrm{CH}$; C-8), $128.5\left(\mathrm{CH} ; \mathrm{C}-5^{\prime}\right), 126.9\left(\mathrm{C} ; \mathrm{C}-1^{\prime}\right), 125.0\left(\mathrm{CH} ; \mathrm{C}-6^{\prime}\right)$, $124.2\left(\mathrm{CH} ; \mathrm{C}-3^{\prime}\right), 115.2(\mathrm{CH} ; \mathrm{C}-7), 113.6$ (C; C-13), 111.7 (CH; C-2), $108.6(\mathrm{C}$; C-12), $107.6(\mathrm{CH} ; \mathrm{C}-5), 101.6(\mathrm{CH} ; \mathrm{C}-4)$, 84.1 (C; C-9), $66.6\left(\mathrm{CH}_{2}\right.$; C-2a, 6a), $44.4\left(\mathrm{CH}_{2} ; \mathrm{C}-3 \mathrm{a}, 5 \mathrm{a}\right)$.

${ }^{1} \mathrm{H}$ NMR $\left(600 \mathrm{MHz}, \mathrm{D}_{2} \mathrm{O}+5 \%\right.$ DMSO- $\left.d_{6}\right): \delta(\mathrm{ppm}) 8.02$ (d, $J=7.3 \mathrm{~Hz}, 1 \mathrm{H}$; H-6 $\left.{ }^{\prime}\right), 7.89(\mathrm{~s}, 1 \mathrm{H} ; \mathrm{H}-5), 7.78(\mathrm{t}, J=7.3 \mathrm{~Hz}$, $\left.1 \mathrm{H} ; \mathrm{H}-5^{\prime}\right), 7.75\left(\mathrm{t}, J=7.3 \mathrm{~Hz}, 1 \mathrm{H} ; \mathrm{H}-4^{\prime}\right), 7.45(\mathrm{~d}, J=8.6 \mathrm{~Hz}, 1 \mathrm{H}$; H-8), 7.44 (d, $J=8.6 \mathrm{~Hz}, 1 \mathrm{H} ; \mathrm{H}-1), 7.40$ (d, $J=7.3 \mathrm{~Hz}, 1 \mathrm{H}$, $\mathrm{H}-3^{\prime}$ ), 7.36 (d, $\left.J=8.6 \mathrm{~Hz}, 1 \mathrm{H} ; \mathrm{H}-7\right), 7.00$ (d, $J=10.6 \mathrm{~Hz}, 1 \mathrm{H}$; $\mathrm{H}-2$ ), 6.95 (s, 1H; H-4), 3.82 (t, J=4.6 Hz, 4H; H-2a, 6a), 3.82 $(\mathrm{t}, J=4.6 \mathrm{~Hz}, 4 \mathrm{H} ; 3 \mathrm{a}, 5 \mathrm{a})$. Carbon signals as derived from HSQC and HMBC NMR measurements $\left(\mathrm{D}_{2} \mathrm{O}+5 \%\right.$ DMSO$\left.d_{6}\right): \delta(\mathrm{ppm}) 164\left(\mathrm{COO}^{-}\right), 160.8$ (C-3), 160 (C-14), 159.8 (C-11), 156 (CO), 155.1 (C-6), 147.6 (C-9), 137.8 (C-1'), 133 (C-1), 131.3 (C-2'), 130.4 (C-8), $130.2\left(\mathrm{C}-4^{\prime}\right) 129.9\left(\mathrm{C}-5^{\prime}\right)$, $129.6\left(\mathrm{C}-3^{\prime}\right), 128.9\left(\mathrm{C}-6^{\prime}\right), 118.7$ (C-2), 118.1 (C-7), $116(\mathrm{C}-$ 13), 116.1 (C-12), 105.4 (C-5), 97.4 (C-4), 66.1 (C-2a, 6a), 44.3 (C-3a, 5a). (See Chart 1 for atom numbering and molecular structure in different solutions.) 
suc-AlaAlaProPhe-Rh110-MC; sucAAPF-Rh110-MC. TBTU $\left(N, N, N^{\prime}, N^{\prime}\right.$-tetramthyl-o-(benzotriazol-1-yl)uranium tetrafluoroborate) was obtained from Novabiochem and Boc-(L)-AlaAlaPro-OH from Bachem. A mixture of TBTU (215 mg, $0.7 \mathrm{mmol}$ ) and DIPEA $(350 \mu \mathrm{L}, 2 \mathrm{mmol})$ was dissolved in $1 \mathrm{~mL}$ of dry DMF and added to Boc-L-Phe-OH $(180 \mathrm{mg}, 0.7 \mathrm{mmol})$ dissolved in $2 \mathrm{~mL}$ of dry $\mathrm{CH}_{2} \mathrm{Cl}_{2}$ under Ar. MC-Rh110 (50 mg, $0.1 \mathrm{mmol}$ ) was dissolved in $1 \mathrm{~mL}$ dry $\mathrm{CH}_{2} \mathrm{Cl}_{2}$ and slowly added to the reaction. After $17 \mathrm{~h}$ of stirring, the solvents were evaporated and the crude mixture was directly purified by HPLC using an acetonitrile/water gradient (12-100\% ACN). Yield: $40 \%(30 \mathrm{mg}, 0.04 \mathrm{mmol})$ BocPhe-Rh110-MC. MS (ESI+): $692\left(\mathrm{MH}^{+}\right)$.

Deprotection of Phe was achieved by slow addition of 50/50 (v/v) TFA $/ \mathrm{CH}_{2} \mathrm{Cl}_{2}(3 \mathrm{~mL})$ to Boc-Phe-Rh110-MC (30 mg, $0.04 \mathrm{mmol})$ in $\mathrm{CH}_{2} \mathrm{Cl}_{2}(1.5 \mathrm{~mL})$. After $3 \mathrm{~h}$, the reaction was stopped and concentrated under vacuum. MS (ESI+): 592 $\left(\mathrm{MH}^{+}\right)$

TBTU (32 mg, $0.1 \mathrm{mmol})$ and DIPEA (40 $\mu \mathrm{L}, 0.2 \mathrm{mmol})$ were dissolved in $1 \mathrm{~mL}$ of dry DMF and added to a solution of Boc-(L)-AlaAlaPro-OH (35 mg, $0.1 \mathrm{mmol}$ in $3 \mathrm{~mL}$ dry THF), kept at $0{ }^{\circ} \mathrm{C}$ under Ar. The reaction mixture was stirred for 10 min after which it was left to warm to room temperature. The Phe-Rh110-MC was dissolved in $1 \mathrm{~mL}$ of dry THF and added to the above mixture. After stirring the reaction mixture at $37^{\circ} \mathrm{C}$ for $12 \mathrm{~h}$, the solvents were evaporated and the mixture was purified by HPLC (45\% ACN in water; isocratic). Yield: $52 \%$ (21 mg, $0.02 \mathrm{mmol}$ ) Boc-AlaAlaProPhe-Rh110-MC. MS (ESI+): $931\left(\mathrm{MH}^{+}\right)$.

The Boc group was removed as described above and the deprotected product was succinylated in $4 \mathrm{~mL}$ THF using triethylamine $(25 \mu \mathrm{L}, 0.2 \mathrm{mmol})$ and succinic anhydride $(10$ $\mathrm{mg}, 0.1 \mathrm{mmol}$ ) at $37^{\circ} \mathrm{C}$ for $10 \mathrm{~h}$. The mixture was purified by HPLC (35\% ACN in water; isocratic). Yield: 67\% (14 mg, $0.015 \mathrm{mmol})$. MS (ESI+): $931\left(\mathrm{MH}^{+}\right), 953\left(\mathrm{MNa}^{+}\right) .{ }^{1} \mathrm{H} \mathrm{NMR}$ (300 MHz, DMSO): $\delta(\mathrm{ppm}) 9.98(\mathrm{~d}, J=5.4 \mathrm{~Hz}, 2 \mathrm{H}), 8.86(\mathrm{~s}$, $2 \mathrm{H}), 8.09-8.00(\mathrm{~m}, 8 \mathrm{H}), 7.86(\mathrm{dd}, J=1.7 \mathrm{~Hz}, J=4.9 \mathrm{~Hz}, 2 \mathrm{H})$, $7.80(\mathrm{t}, J=7.3 \mathrm{~Hz}, 2 \mathrm{H}), 7.73(\mathrm{t}, J=7.3 \mathrm{~Hz}, 2 \mathrm{H}), 7.68(\mathrm{~d}, J=1.9$ $\mathrm{Hz}, 2 \mathrm{H}), 7.30-7.14(\mathrm{~m}, 20 \mathrm{H}), 6.74(\mathrm{~d}, J=8.7 \mathrm{~Hz}, 2 \mathrm{H}), 6.66$ $(\mathrm{d}, J=8.7 \mathrm{~Hz}, 2 \mathrm{H}), 4.58(\mathrm{dd}, J=1.7 \mathrm{~Hz}, J=4.9 \mathrm{~Hz}, 2 \mathrm{H}), 4.51$ $(\mathrm{t}, J=7.0 \mathrm{~Hz}, 2 \mathrm{H}), 4.28-4.21(\mathrm{~m}, 4 \mathrm{H}), 3.62(\mathrm{~d}, J=1.9 \mathrm{~Hz}$, $2 \mathrm{H}), 7.30-7.14(\mathrm{~m}, 20 \mathrm{H}), 6.74(\mathrm{~d}, J=8.7 \mathrm{~Hz}, 2 \mathrm{H}), 3.15(\mathrm{dd}$, $J=4.7 \mathrm{~Hz}, J=14.7 \mathrm{~Hz}, 2 \mathrm{H}), 2.93(\mathrm{dd}, J=9.4 \mathrm{~Hz}, J=13.7 \mathrm{~Hz}$, $2 \mathrm{H}), 2.40-2.31(\mathrm{~m}, 8 \mathrm{H}), 1.99-1.92(\mathrm{~m}, 2 \mathrm{H}), 1.81-1.76(\mathrm{~m}$, $4 \mathrm{H}), 1.68-1.63(\mathrm{~m}, 2 \mathrm{H}), 1.19-1.14(\mathrm{~m}, 14 \mathrm{H})$.

(suc-Phe) ${ }_{2}-$ Rh110; (suc-F) ${ }_{2}-\mathrm{Rh} 110$. (Boc-Phe) ${ }_{2}$-Rh110 was obtained as the product of the first step of the synthesis of (suc$\mathrm{AAPF})_{2}$-Rh110. It was deprotected and succinylated as described above. After purification by HPLC (37\% ACN in water; isocratic), the desired (suc-F) 2 -Rh110 was obtained. MS (ESI+): $826\left(\mathrm{MH}^{+}\right) .{ }^{1} \mathrm{H}$ NMR $(600 \mathrm{MHz}, \mathrm{DMSO}): \delta(\mathrm{ppm}) 10.39(\mathrm{~s}$, $2 \mathrm{H}), 8.38(\mathrm{~d}, J=7.9 \mathrm{~Hz}, 2 \mathrm{H}), 8.02(\mathrm{~d}, J=7.5 \mathrm{~Hz}, 1 \mathrm{H}), 7.88(2 \mathrm{~s}$, $2 \mathrm{H}), 7.79(\mathrm{t}, J=7.5 \mathrm{~Hz}, 1 \mathrm{H}), 7.72(\mathrm{t}, J=7.5 \mathrm{~Hz}, 1 \mathrm{H}), 7.28-7.21$ (m, 10H), $7.20-7.18(\mathrm{~m}, 2 \mathrm{H}), 6.73(\mathrm{~d}, J=8.7 \mathrm{~Hz}, 2 \mathrm{H}), 4.62(\mathrm{~s}$, $2 \mathrm{H}), 3.07(\mathrm{~d}, J=9.4 \mathrm{~Hz}, 2 \mathrm{H}), 2.87(\mathrm{t}, J=9.7 \mathrm{~Hz}, 2 \mathrm{H}), 2.38-2.24$ (m, 8H). ${ }^{13} \mathrm{C}$ NMR (125 MHz, DMSO): $\delta$ (ppm) $173.8(\mathrm{C})$, 171.3 (C), 170.8 (C), 168.5 (C), 150.6 (C), 140.8 (C), 137.4 (C), $135.4(\mathrm{CH}), 130.0(\mathrm{CH}), 128.9(\mathrm{CH}), 128.2(\mathrm{CH}), 127.9$ $(\mathrm{CH}), 126.2(\mathrm{CH}), 125.6(\mathrm{C}), 124.7(\mathrm{CH}), 123.7(\mathrm{CH}), 115.5$ $(\mathrm{CH}), 113.1(\mathrm{C}), 106.4(\mathrm{CH}), 81.6(\mathrm{C}), 54.8(\mathrm{CH}), 37.3\left(\mathrm{CH}_{2}\right)$, $30.0\left(\mathrm{CH}_{2}\right), 29.7\left(\mathrm{CH}_{2}\right)$.

suc-Phe-Rh110-MC; suc-F-Rh110-MC. Boc-Phe-Rh110-MC was obtained as the product of the first step of the synthesis of
suc-AAPF-Rh110-MC. Deprotection and succinylation was performed as described above. The purified product was eluted from HPLC using 35\% ACN in water (isocratic). MS (ESI+): 692 $\left(\mathrm{MH}^{+}\right) .{ }^{1} \mathrm{H}$ NMR (400 MHz, DMSO): $\delta$ (ppm) $10.51(\mathrm{~s}, 1 \mathrm{H})$, $8.78(\mathrm{~s}, 1 \mathrm{H}), 8.39$ (d, $J=6.5 \mathrm{~Hz}, 2 \mathrm{H}), 7.94(\mathrm{~d}, J=7.8 \mathrm{~Hz}, 1 \mathrm{H})$, $7.90(\mathrm{~s}, 1 \mathrm{H}), 7.72(\mathrm{t}, J=7.3 \mathrm{~Hz}, 1 \mathrm{H}), 7.65(\mathrm{t}, J=7.3 \mathrm{~Hz}, 1 \mathrm{H}), 7.59$ (S, 1H), 7.38-7.35 (m, 1H), 7.21-7.17 (m, 5H), 7.12-7.09 (m $2 \mathrm{H}), 6.64\left(\mathrm{~S}_{\mathrm{br}}, 2 \mathrm{H}\right), 6.60(\mathrm{t}, J=8.3 \mathrm{~Hz}, 4 \mathrm{H}), 4.50-4.48(\mathrm{~m}, 1 \mathrm{H})$, $3.54(\mathrm{t}, J=4.3 \mathrm{~Hz}, 5 \mathrm{H}), 3.37(\mathrm{t}, J=4.8 \mathrm{~Hz}, 5 \mathrm{H}), 3.07(\mathrm{dd}, J=4.0$ $\mathrm{Hz}, J=13.7 \mathrm{~Hz}, 2 \mathrm{H}$ ), 2.80 (dd, $J=9.8 \mathrm{~Hz}, J=13.4 \mathrm{~Hz}, 2 \mathrm{H}), 2.6$ (s, $1 \mathrm{H}), 2.26-2.01(\mathrm{~m}, 5 \mathrm{H})$.

Boc-Phe-Rh110; Boc-F-Rh110. During the synthesis of (BocPhe) ${ }_{2}$-Rh110, monosubstituted Boc-F-Rh110 was obtained as a side product after silica chromatography. It was further purified by HPLC using an ACN/water gradient (10-100\% ACN). MS (ESI+): $579\left(\mathrm{MH}^{+}\right)$. NMR: ${ }^{1} \mathrm{H}$ NMR $\left(600 \mathrm{MHz}, \mathrm{CDCl}_{3}\right): \delta$ (ppm) 7.99 (d, $J=7.5 \mathrm{~Hz}, 1 \mathrm{H}), 7.68-7.56(\mathrm{~m}, 3 \mathrm{H}), 7.30$ (d, $J=$ $6.8 \mathrm{~Hz}, 1 \mathrm{H}), 7.29-7.21(\mathrm{~m}, 3 \mathrm{H}), 7,14(\mathrm{~d}, J=6.8 \mathrm{~Hz}, 1 \mathrm{H}), 6.79$ $\left(\mathrm{s}_{\mathrm{b}}, 1 \mathrm{H}\right), 6.65(\mathrm{~d}, J=8.3 \mathrm{~Hz}, 1 \mathrm{H}), 6.55-6.51(\mathrm{~m}, 2 \mathrm{H}), 6.34(\mathrm{~d}, J=$ $7.9 \mathrm{~Hz}, 1 \mathrm{H}), 5.10(\mathrm{~s}, 1 \mathrm{H}), 4.44(\mathrm{~s}, 1 \mathrm{H}), 3.90(\mathrm{~s}, 2 \mathrm{H}), 3.15(\mathrm{~s}, 2 \mathrm{H})$, $1.42(\mathrm{~s}, 9 \mathrm{H}) .{ }^{13} \mathrm{C} \mathrm{NMR}\left(125 \mathrm{MHz} \mathrm{CDCl}_{3}\right): \delta(\mathrm{ppm}) 177.6(\mathrm{C})$, 169.8 (C), 153.4 (C), 152.6 (C), 152.0 (C), 149.0 (C), 139.2 (C), $135.0(\mathrm{CH}), 129.7(\mathrm{CH}), 129.4(\mathrm{CH}), 129.3(\mathrm{CH}), 129.1$ (CH), $128.7(\mathrm{CH}), 127.4(\mathrm{CH}), 127.0(\mathrm{C}), 125.1(\mathrm{CH}), 124.1$ $(\mathrm{CH}), 115.2(\mathrm{CH}), 111.8(\mathrm{CH}), 108.6(\mathrm{C}), 108.0(\mathrm{CH}), 101.6$ (CH), $100.1(\mathrm{C}), 83.5(\mathrm{C}), 56.8(\mathrm{CH}), 38.1\left(\mathrm{CH}_{2}\right), 28.4\left(\mathrm{CH}_{3}\right)$.

Boc-AlaAlaProPhe-Rh110; Boc-AAPF-Rh110. For the synthesis of this compound, the coupling of Boc-AlaAlaPro-OH to Phe-Rh110 was not possible, as the peptide might also react with the second amino group of Rh110. Instead, the 4 amino-acidlong peptide Boc-AlaAlaProPhe- $\mathrm{OH}$ was coupled to $\mathrm{Rh} 110$ directly. In the first step, the peptide Boc-AlaAlaProPhe-OH was synthesized. Boc-AlaAlaPro-OH $(200 \mathrm{mg}, 0.6 \mathrm{mmol})$ was dissolved in $10 \mathrm{~mL}$ of anhydrous THF at $0{ }^{\circ} \mathrm{C}$. To this solution, a mixture of TBTU $(180 \mathrm{mg}, 0.6 \mathrm{mmol})$ and DIPEA $(130 \mu \mathrm{L}, 0.7$ $\mathrm{mmol}$ ), dissolved in $2 \mathrm{~mL}$ dry DMF, was added. After $10 \mathrm{~min}$, the cooling bath was removed and the reaction mixture was allowed to warm to room temperature. Phe-OMe $(160 \mathrm{mg}, 0.7 \mathrm{mmol})$, dissolved in $4 \mathrm{~mL}$ dry DMF, was added slowly to the above mixture. After $20 \mathrm{~h}$ of stirring, the solvents were evaporated and the crude mixture was purified on a silica gel column using $\mathrm{CH}_{2} \mathrm{Cl}_{2} / \mathrm{MeOH}(9: 1)$ as the eluent. Removal of the methyl group was carried out in $\mathrm{CH}_{2} \mathrm{Cl}_{2}$ and $0.3 \mathrm{M} \mathrm{NaOH}$. After that, the reaction was neutralized by $\mathrm{HCl}$ and again purified on a silica gel column using $\mathrm{CH}_{2} \mathrm{Cl}_{2} / \mathrm{MeOH}$ (9:1) as the eluent. Yield: $83 \%$ (250 mg, $0.5 \mathrm{mmol})$. MS (ESI+): $527\left(\mathrm{MNa}^{+}\right)$.

Boc-AlaAlaProPhe-OH (53 mg, $0.1 \mathrm{mmol})$, TBTU (41 mg, $0.1 \mathrm{mmol})$ and DIPEA $(75 \mu \mathrm{L}, 0.4 \mathrm{mmol})$ were dissolved in $2 \mathrm{~mL}$ of dry DMF. To this mixture, Rhodamine 110 chloride $(22 \mathrm{mg}$, $0.06 \mathrm{mmol}$ in $1 \mathrm{~mL}$ dry DMF) was added and the solution was stirred overnight at $37^{\circ} \mathrm{C}$. The resulting mixture was evaporated and purified by HPLC (40\% ACN in water; isocratic). The yield was only $2 \%(1.2 \mathrm{mg})$. MS (ESI+): $818\left(\mathrm{MH}^{+}\right)$. This low yield was expected, as it has been shown before that the coupling of the complete 4 amino-acid-long peptide is much less efficient than the sequential coupling of amino acids in a multistep reaction. ${ }^{18}$

Kinetic Measurements. Chymotrypsin ( $\alpha$-Chymotrypsin from bovine pancreas; Fluka) was dissolved in PBS (10 mM phosphate $\mathrm{pH}$ 7.4, $138 \mathrm{mM} \mathrm{NaCl}, 2.7 \mathrm{mM} \mathrm{KCl}$; Sigma). Substrates were prepared as stock solutions in DMSO. Reactions were started by adding $190 \mu \mathrm{L}$ of chymotrypsin in PBS to $10 \mu \mathrm{L}$ of a substrate solution in the cuvette. The final enzyme 


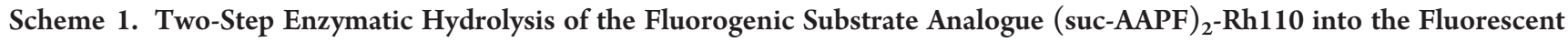
Product Rhodamine 110 Showing the Production of the Less Fluorescent Intermediate

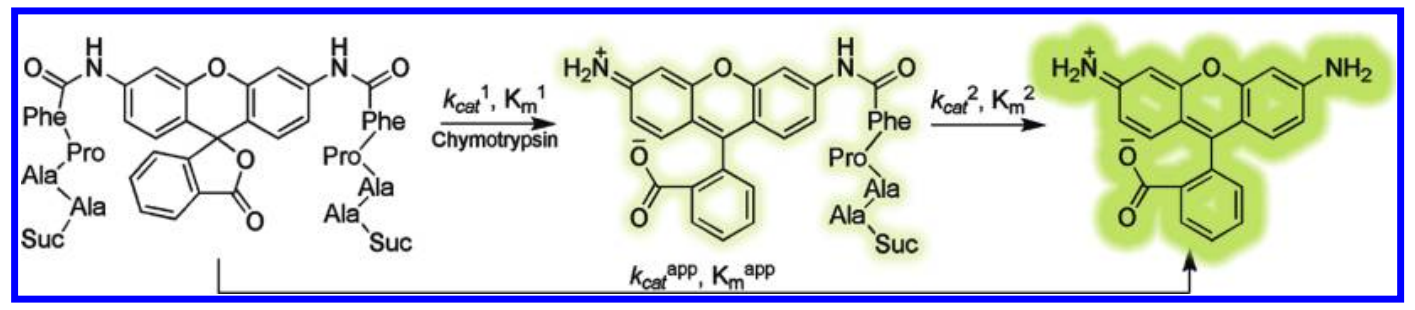

Scheme 2. One-Step Enzymatic Hydrolysis of the Fluorogenic Substrate Analogue (suc-AAPF)-Rh110-MC into the Fluorescent Product MC-Rh110

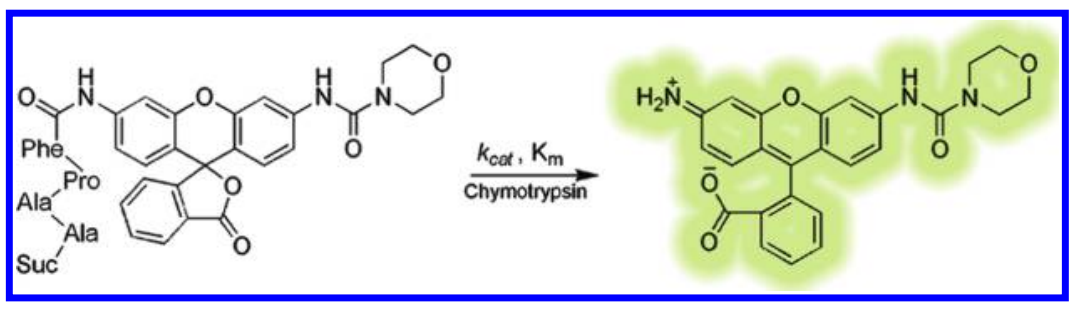

concentration was $3 \mathrm{nM}$ for (suc-AAPF) ${ }_{2}$-Rh110 and suc-AAPFRh110-MC or $900 \mathrm{nM}$ for (suc-F) ${ }_{2}$-Rh110 and suc-F-Rh110MC. The substrate concentrations varied between 0.4 and 50 $\mu \mathrm{M}$. Product formation was followed by recording fluorescence $\left(\lambda_{\mathrm{ex}}=488 \mathrm{~nm} ; \lambda_{\mathrm{em}}=520 \mathrm{~nm}\right)$ with a Photon Technology International fluorescence spectrometer. The emission intensity was converted into product concentrations using calibration curves of Rh110 or MC-Rh110, respectively. $K_{\mathrm{m}}, k_{\text {cat }}$, and $k_{\text {cat }} / K_{\mathrm{m}}$ values were obtained by least-squares fitting of the data to the Michaelis-Menten equation using Origin (see Supporting Information).

Determination of the Absorption and Emission Spectra. Rhodamine 110 chloride (Bioreagent, Sigma) was used to study the photophysical properties. Absorption measurements were performed with a Lambda $40 \mathrm{UV} /$ vis spectrometer (PerkinElmer). For the fluorescence measurements, a Photon Technology International fluorescence spectrometer was used.

Fluorescence Lifetime Measurements. Excited-state lifetimes were determined using time-correlated single photon counting (TCSPC). The instrument response function (IRF) was recorded using a LUDOX scattering solution and its fwhm amounted to $\sim 40 \mathrm{ps}$. The fluorescence decay curves were analyzed by being fitted to a convolution of the IRF with a decay function for a $\delta$-pulse using a TRFA Global Analysis Program based on a Marquard-Levenberg least-squares fitting. The quality of the fit was judged according the criteria published by Boens et al. ${ }^{23}$

Determination of the Quantum Yield. Quantum yield measurements were performed with an integrating sphere using a Fluorolog 3 fluorescence spectrometer (Horiba Jobin Yvon). The procedure as well as the calculations are described in the work of de Mello. ${ }^{24}$ The measurements of the fluorophore solutions (absorption between 0.07 and 0.15 ) were performed in triplicate.

\section{RESULTS AND DISCUSSION}

For the enzyme activity measurements, the following substrate analogues were synthesized: (suc-AAPF) 2 -Rh110, suc-AAPF-
Rh110-MC, (suc-F) 2 -Rh110, and suc-F-Rh110-MC. These molecules were nonfluorescent and stable in aqueous solution. No autohydrolysis could be detected. The bis-amide substrate analogues (suc-AAPF) $)_{2}$-Rh110 and (suc-F) $)_{2}$-Rh110 are hydrolyzed by the enzyme following the two-step reaction shown in Scheme 1 . The hydrolysis of the monoamide substrate analogues suc-AAPF-Rh110-MC and suc-F-Rh110-MC follows the reaction of Scheme 2.

Enzymatic activity was measured over a range of substrate concentrations (at least 12 data points) in order to determine the kinetic constants. At least one reaction in each series was followed to completion. In this way, the final product concentration could be determined, which corresponds directly to the initial substrate concentration. This approach yields an accurate value of the substrate concentration even if the respective compound contains noncleavable components such as molecules with $\mathrm{D}$-amino acids that have not been completely removed during purification.

The results (Table 1 ) clearly show that the activity of $\alpha$ chymotrypsin is higher for the substrate analogues containing the AAPF sequence instead of phenylalanine only. It has been observed before that the activity of $\alpha$-chymotrypsin increases with increasing length of the peptide. ${ }^{25}$ More interesting are, however, the differences between the peptide-Rh110-MC and the bis-amide Rh1 10 substrate analogues. For both the 4 aminoacid-long and the 1 amino-acid-long peptides, the $k_{\text {cat }}$ values for the peptide-Rh110-MC based substrate analogue are higher than for the (peptide) $)_{2}$-Rh110 substrate analogue. This is expected when considering that the cleavage of the bis-amide substrate analogue (Scheme 1) involves the less fluorescent intermediate. When using the fluorescence of the product as the calibration, the actual number of cleaved bonds is underestimated due to the presence of the intermediate leading to a lower measured reaction velocity and $k_{\text {cat }}{ }^{\text {app }}$ value. The lower $K_{\mathrm{m}}$ app values for the (peptide) $)_{2}$-Rh110 substrate analogues can potentially result from a higher effective molarity of the cleavable 
bonds or rebinding of the intermediate after hydrolysis of the first bond. Although we cannot exclude that the MC-moiety influences the binding of the substrate analogues to the enzyme, it appears likely that the kinetic parameters obtained from the hydrolysis of the monoamide peptide-Rh110-MC substrate analogue represent the true kinetic constants related to peptide-bond cleavage. The result that the determined $k_{\text {cat }}$ app and $K_{\mathrm{m}}{ }^{\text {app }}$ values for the double-substituted substrate analogue do not resemble the real kinetic constants is further supported by the observation that the two cleavage steps are characterized by different kinetic constants as has been shown for other fluorogenic substrate analogues before. ${ }^{13}$

Making several assumptions, we have also made an attempt to calculate the individual kinetic constants of the two-step hydrolysis reaction (see Supporting Information). While the calculated $k_{\mathrm{cat}} / K_{\mathrm{m}}$ values for the individual reaction steps have a large error, they are clearly different from each other and from the apparent values. This further emphasizes the problem associated with obtaining kinetic constants for double-substituted substrate analogues. In summary, these results show that the apparent $K_{\mathrm{m}}{ }^{\text {app }}$ and $k_{\text {cat }}{ }^{\text {app }}$ values determined for the double-substituted Rh110 substrate analogues are not the true rate constants characterizing the enzymatic reaction. Clearly, there is no accurate way to determine these from an assay purely based on fluorescence. Monosubstituted substrate analogues such as peptide-Rh110-MC are required for an accurate determination of $K_{\mathrm{m}}$ and $k_{\text {cat }}$.

In order to obtain a more detailed picture of the molecular mechanism determining the fluorescence of MC-Rh110, we also synthesized the monosubstituted peptide-Rh110 derivatives. We expected that a comparison of MC-Rh110 with Boc-F-Rh110 and Boc-AAPF-Rh110 as well as with Rh110 would give insight into the properties determining the high fluorescence intensity of

\section{Table 1. Kinetic Parameters for the $\alpha$-Chymotrypsin Cata-} lyzed Hydrolysis of the Substrate Analogues with One and Two Cleavable Peptide Bonds

\begin{tabular}{|cccc} 
substrate analogue & $k_{\text {cat }}\left[\mathrm{s}^{-1}\right]$ & $K_{\mathrm{m}}[\mu \mathrm{M}]$ & $\begin{array}{c}k_{\text {cat }} / K_{\mathrm{m}} \\
{\left[\mathrm{M}^{-1} \mathrm{~s}^{-1}\right]}\end{array}$ \\
$\begin{array}{c}\text { (suc-AAPF })_{2} \text {-Rh110 } \\
\text { apparent }\end{array}$ & $0.43 \pm 0.03$ & $8.7 \pm 1.6$ & $(5.0 \pm 1) \times 10^{4}$ \\
suc-AAPF-Rh110-MC & $11 \pm 1$ & $68 \pm 7$ & $(16 \pm 2) \times 10^{4}$ \\
$\begin{array}{l}\text { (suc-F) })_{2} \text {-Rh110 apparent } \\
\text { suc-F-Rh110-MC }\end{array}$ & $0.0035 \pm 0.0003$ & $31 \pm 4$ & $(1.1 \pm 0.2) \times 10^{2}$ \\
& $0.054 \pm 0.006$ & $182 \pm 23$ & $(3.0 \pm 0.5) \times 10^{2}$
\end{tabular}

MC-Rh110. The Boc-protected analogues were used instead of the succinylated peptides, because they are easier to obtain in high purity, which is essential for spectroscopic measurements. The Boc-group is not expected to affect the structural and photophysical properties as it has been shown before that only the amino acid closest to the fluorophore determines its properties. ${ }^{26}$ The latter is confirmed by our measurements that show similar photophysical properties for Boc-F-Rh110 and BocAAPF-Rh110 (see Supporting Information).

For both MC-Rh110 and Boc-F-Rh110, we have observed that their solutions in chloroform do not absorb visible light. This suggests their presence in the nonfluorescent lactone form, which is confirmed by NMR spectra. The ${ }^{1} \mathrm{H}$ signals for protons $1,2,7$, and 8 of the xanthene moiety are shielded, and the carbon ${ }^{13} \mathrm{C}$ signal at $84 \mathrm{ppm}$ corresponds to carbon 9 (see Supporting Information). Combining the ${ }^{13} \mathrm{C}$ and DEPT spectra indicates that the number of carbons is compatible with the presence of a single molecular species. When these molecules are dissolved in water, however, they absorb in the blue region with a maximum absorption coefficient of 24600 and $52000 \mathrm{M}^{-1} \mathrm{~cm}^{-1}$ for BocF-Rh110 and MC-Rh110, respectively. NMR measurements of MC-Rh110 in $\mathrm{D}_{2} \mathrm{O} / \mathrm{DMSO}$ (5\%) confirm the formation of the open zwitterionic form and do not indicate the presence of more than one species. The carbon signals of the benzene ring and C-2, 3 of the xanthene moiety show very similar ppm values as for unsubstituted Rh110 (see Supporting Information). ${ }^{27}$ X-ray diffraction analysis of MC-Rh110 single-crystals, obtained from the slow evaporation of a methanol solution, also revealed the open ionic conformation. Methanol as a medium corresponds to a polar environment just as in an aqueous solution. In conclusion, we suggest that the previously proposed conformational equilibrium of monosubstituted Rh110 molecules is completely shifted to the lactone form in a nonpolar solution. In contrast, all molecules adopt the open ionic form in a water solution. This result is further supported by the photophysical properties of Boc-F-Rh110 and MC-Rh110 that obviously suggest a different reason for the decrease in fluorescence intensity from Rh110 to MC-Rh110 and Boc-F-Rh110.

The data presented in Figure 1 and Table 2 show that the attachment of a substituent to one of the amino groups of Rh110 leads to a blue shift of the absorption maximum, a red shift of the emission maximum, an increased bandwidth, and vibrational progression in the absorption and emission spectra. This is accompanied by a decrease of the fluorescence quantum yield. This effect is more pronounced for Boc-F-Rh110 than for MCRh110. These results can be rationalized by considering the

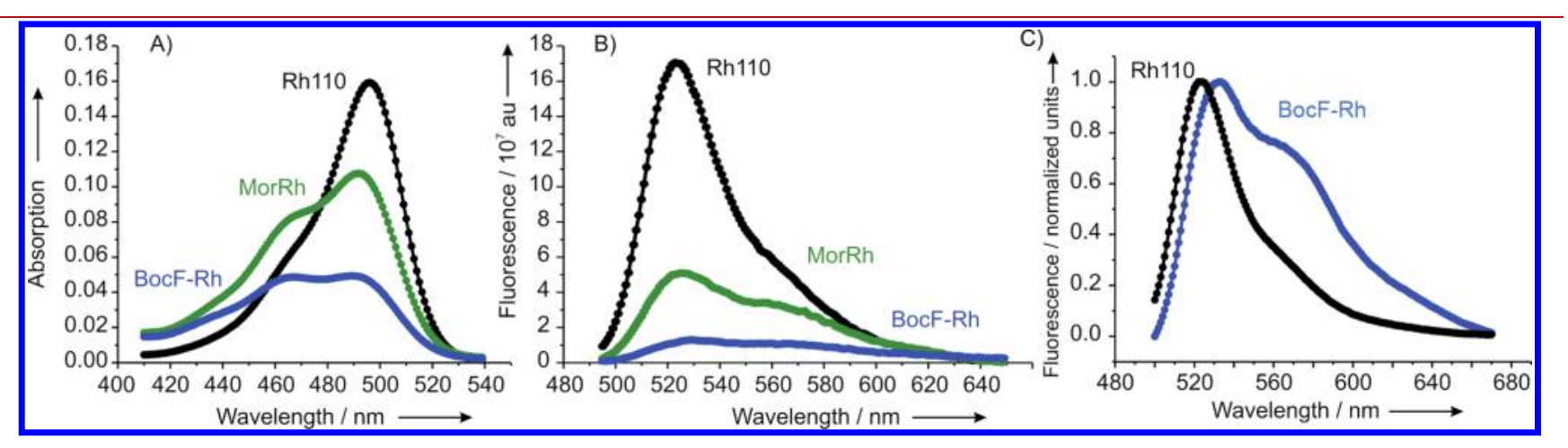

Figure 1. (A) Absorption and (B) emission spectra of Rhodamine 110, morpholinecarbonyl-Rh110, and BocF-Rh110; (C) normalized emission spectra of Rhodamine 110 and its monosubstituted peptide derivative. 
Table 2. Spectroscopic Properties of Rhodamine110 and Its Monoderivatives

\begin{tabular}{|c|c|c|c|c|c|}
\hline molecule & fluorescence lifetime [ns] & $\Phi_{488}$ & $\lambda_{\max \text { abs }}[\mathrm{nm}] \lambda_{\max \text { em }}[\mathrm{nm}]$ & $\varepsilon_{488}\left[\mathrm{M}^{-1} \mathrm{~cm}^{-1}\right]$ & Fl. Int $(\text { rel })^{a}$ \\
\hline Rhodamine 110 & $\begin{array}{l}4.0 \\
\left(2.4 \times 10^{8}\right)^{b} \\
\left(7.5 \times 10^{6}\right)^{c}\end{array}$ & $\begin{array}{r}0.97 \\
\pm 0.05\end{array}$ & $\begin{array}{l}495 \\
523\end{array}$ & 69000 & 1 \\
\hline MC-Rh110 & $\begin{array}{l}3.6 \\
\left(1.7 \times 10^{8}\right)^{b} \\
\left(1.1 \times 10^{8}\right)^{c}\end{array}$ & $\begin{array}{r}0.60 \\
\pm 0.03\end{array}$ & $\begin{array}{l}492 \\
525\end{array}$ & 52000 & 0.3 \\
\hline$\lambda_{\mathrm{ex}}=488 \mathrm{~nm}$, & $\begin{array}{c}2.8 \\
\left(1.1 \times 10^{8}\right)^{b} \\
\left(2.5 \times 10^{8}\right)^{c} \\
\mathrm{~nm} \cdot{ }^{b} k_{\mathrm{f}}\left[\mathrm{s}^{-1}\right] \cdot{ }^{c} k_{\mathrm{nr}}\left[\mathrm{s}^{-}\right.\end{array}$ & $\begin{array}{r}0.31 \\
\pm 0.02\end{array}$ & $\begin{array}{l}489 \\
529\end{array}$ & 24600 & 0.1 \\
\hline
\end{tabular}

resonance forms of the dyes. For Rh110, two equivalent and isoenergetic resonance forms exist with the positive charge on the left and right amino groups, respectively. For MC-Rh110, the attachment of an electron withdrawing amide moiety to one of the amino groups destabilizes the resonance form with the positive charge on the corresponding amino group. For Boc-FRh110, this resonance form is even more destabilized as the electron withdrawing character of the carbonyl is no longer attenuated by the electron donating morpholino moiety. As both resonance forms are no longer iso-energetic, there is an alternation of single and double bonds in the xanthenium cation leading to a blue shift of the absorption. Furthermore, the alternation of single and double bonds increases upon excitation which leads to increased electron phonon coupling and hence increased vibrational progression. The asymmetry furthermore leads to a dipole moment along the long axis of the molecule that is different in the excited state and the ground state. This difference in dipole moment leads to an increased Stokes shift and hence a red shift of the fluorescence. Furthermore, the increased asymmetry of the $\pi$-cloud results in a reduced transition dipole moment between the $S_{0}$ and $S_{1}$ states that is reflected in the fluorescent rate constant. The molar extinction coefficient at the maximum shows an even stronger decrease resulting from the combination of an increased electron phonon coupling and a decreased transition dipole moment. Finally, the increased electron phonon coupling also leads to an increase of the nonradiative decay rate from $7.5 \times$ $10^{6} \mathrm{~s}^{-1}$ in Rh110 over $1.1 \times 10^{8} \mathrm{~s}^{-1}$ in MC-Rh110 and $2.5 \times$ $10^{8} \mathrm{~s}^{-1}$ in Boc-F-Rh110. Finally, it should be noted that the fluorescence lifetimes measured at both maxima of Boc-FRh110 are the same, indicating that they must be attributed to the same emitting species. Overall, our results clearly suggest that the differences in fluorescence intensity do not originate from the proposed equilibrium between a lactone form and a zwitterionic form but result from differences in the electron structure of the monosubstituted Rh110 derivatives.

The absence of this equilibrium is important information for single molecule experiments, where it is essential that the fluorophore population studied is homogeneous. Thus, the chemical properties of MC-Rh110 in principle make it an ideal fluorophore for preparing substrate analogues with 1:1 stoichiometry for the analysis of enzyme kinetics at the single molecule level. However, not only the chemical properties ensure that each generated product molecule can be detected individually as a fluorescent signal. ${ }^{21,28} \mathrm{MC}-\mathrm{Rh} 110$ further shows sufficient brightness to be detected at the single molecule level. It is therefore our next goal to investigate if
suc-AAPF-Rh110-MC and (suc-AAPF) 2 -Rh110 also yield different kinetic parameters in single molecule experiments where the intermediate is probably not detected due to its low brightness.

In conclusion, we have synthesized a series of fluorogenic substrate analogues for $\alpha$-chymotrypsin. We have shown that only substrate analogues with one cleavable bond give access to the real kinetic constants of the enzymatic reaction. The origin of the relatively high fluorescence of the morpholinecarbonyl monosubstituted Rh110 was established. We anticipate that the fluorescence of monosubstituted fluorescein derivatives is determined by the same mechanism and that in aqueous solution xanthene dyes in general adopt an open ionic form. This information is vital for the development of the next generation of monosubstituted fluorogenic substrate analogues, e.g., with improved solubility or cell permeability, which might ultimately allow the study of single enzyme molecules in living systems.

\section{ASSOCIATED CONTENT}

S Supporting Information. Calculation of the individual kinetic constants of the two-step hydrolysis reaction, and comparison of the fluorescent properties of monoamide Rh110 derivatives and NMR data. This material is available free of charge via the Internet at http://pubs.acs.org

\section{AUTHOR INFORMATION}

\section{Corresponding Author}

*Tel: (+) 31 (0) 24365 2464. Fax: (+) 31 (0) 243652929.

E-mail: k.blank@science.ru.nl.

\section{ACKNOWLEDGMENT}

The authors thank Prof. Alan E. Rowan for helpful discussions, Kristof Van Hecke for the crystal structure analysis, and Karel Duerinckx for the NMR measurements. Financial support of the "Fonds voor Wetenschappelijk Onderzoek FWO" (Grant G.0402.09, G.0413.10, G.0697.11), the K. U. Leuven Research Fund (GOA 2011/03), the Flemish government (Long term structural funding - Methusalem funding CASAS METH/08/ 04), and the Federal Science Policy of Belgium (IAP-VI/27) is gratefully acknowledged. K. B. acknowledges support from a long-term fellowship from the Human Frontier Science Program (HFSP) and a VIDI grant from The Netherlands Organisation for Scientific Research (NWO). 


\section{REFERENCES}

(1) Turk, B. (2006) Targeting proteases: successes, failures and future prospects. Nat. Rev. Drug Discovery 5, 785-99.

(2) Rotman, B. (1961) Measurement of activity of single molecules of beta-D-galactosidase. Proc. Natl. Acad. Sci. U. S. A. 47, 1981-1991.

(3) Chen, X., Sun, M., and Ma, H. (2006) Progress in spectroscopic probes with cleavable active bonds. Curr. Org. Chem. 10, 477-489.

(4) Lavis, L. D., and Raines, R. T. (2008) Bright ideas for chemical biology. ACS Chem. Biol. 3, 142-155.

(5) Marmé, N., Knemeyer, J.-P., Wolfrum, J., and Sauer, M. (2004) Highly sensitive protease assay using fluorescence quenching of peptide probes based on photoinduced electron transfer. Angew. Chem., Int. Ed. 43, 3798-3801.

(6) Matayoshi, E., Wang, G., Krafft, G., and Erickson, J. (1990) Novel fluorogenic substrates for assaying retroviral proteases by resonance energy transfer. Science 247, 954-958.

(7) Mitra, R. D., Silva, C. M., and Youvan, D. C. (1996) Fluorescence resonance energy transfer between blue-emitting and red-shifted excitation derivatives of the green fluorescent protein. Gene 173, 13-17.

(8) Boonacker, E., and Van Noorden, C. J. F. (2001) Enzyme cytochemical techniques for metabolic mapping in living cells, with special reference to proteolysis. J. Histochem. Cytochem. 49, 1473-1486.

(9) Boonacker, E., Elferink, S., Bardai, A., Fleischer, B., and Van Noorden, C. J. (2003) Fluorogenic substrate [Ala-Pro]2-cresyl violet but not Ala-Pro-rhodamine 110 is cleaved specifically by DPPIV activity: a study in living Jurkat cells and CD26/DPPIV-transfected Jurkat cells. J. Histochem. Cytochem. 51, 959-68.

(10) Rotman, B., Zderic, J. A., and Edelstein, M. (1963) Fluorogenic substrates for beta-D-galactosidases and phosphatases derived from flurescein (3,6-dihydroxyfluoran) and its monomethylether. Proc. Natl. Acad. Sci. U. S. A. 50, 1-6.

(11) Corey, P. F., Trimmer, R. W., and Biddlecom, W. G. (1991) A new chromogenic $\beta$-galactosidase substrate: $7-\beta$-D-Galactopyranosyloxy9,9-dimethyl-9H-acridin-2-one. Angew. Chem., Int. Ed. 30, 1646-1648.

(12) Van Noorden, C. J., Boonacker, E., Bissell, E. R., Meijer, A. J., van Marle, J., and Smith, R. E. (1997) Ala-Pro-cresyl violet, a synthetic fluorogenic substrate for the analysis of kinetic parameters of dipeptidyl peptidase IV (CD26) in individual living rat hepatocytes. Anal. Biochem. $252,71-7$.

(13) Hofmann, J., and Sernetz, M. (1983) A kinetic study on the enzymatic hydrolysis of fluoresceindiacetate and fluorescein-di-[beta]galactopyranoside. Anal. Biochem. 131, 180-186.

(14) Huang, Z. J. (1991) Kinetic fluorescence measurement of fluorescein di-beta-D-galactoside hydrolysis by beta-galactosidase: intermediate channeling in stepwise catalysis by a free single enzyme. Biochemistry 30, 8535-40.

(15) Leytus, S. P., Melhado, L. L., and Mangel, W. F. (1983) Rhodamine-based compounds as fluorogenic substrates for serine proteinases. Biochem. J. 209, 299-307.

(16) Cai, S. X., Zhang, H.-Z., Guastella, J., Drewe, J., Yang, W., and Weber, E. (2001) Design and synthesis of Rhodamine 110 derivative and Caspase-3 substrate for enzyme and cell-based fluorescent assay. Bioorg. Med. Chem. Lett. 11, 39-42.

(17) Lorey, S., Faust, J., Mrestani-Klaus, C., Kahne, T., Ansorge, S., Neubert, K., and Buhling, F. (2002) Transcellular proteolysis demonstrated by novel cell surface-associated substrates of dipeptidyl peptidase IV (CD26). J. Biol. Chem. 277, 33170-7.

(18) Zhang, H. Z., Kasibhatla, S., Guastella, J., Tseng, B., Drewe, J., and Cai, S. X. (2003) N-Ac-DEVD-N'-(Polyfluorobenzoyl)-R110: novel cell-permeable fluorogenic caspase substrates for the detection of caspase activity and apoptosis. Bioconjugate Chem. 14, 458-63.

(19) Lavis, L. D., Chao, T.-Y., and Raines, R. T. (2006) Fluorogenic label for biomolecular imaging. ACS Chem. Biol. 1, 252-260.

(20) Wang, Z. Q. Liao, J., and Diwu, Z. (2005) N-DEVD-N'morpholinecarbonyl-rhodamine 110: novel caspase-3 fluorogenic substrates for cell-based apoptosis assay. Bioorg. Med. Chem. Lett. 15, 2335-8.

(21) De Cremer, G., Roeffaers, M. B., Baruah, M., Sliwa, M., Sels, B. F., Hofkens, J., and De Vos, D. E. (2007) Dynamic disorder and stepwise deactivation in a chymotrypsin catalyzed hydrolysis reaction. L. Am. Chem. Soc. 129, 15458-9.

(22) Diwu, Z., Liao, J., Wang, Z. (2003) Luminogenic protease substrates. U.S. Patent application, WO2003099780.

(23) Boens, N., Qin, W., Basaric, N., Hofkens, J., Ameloot, M., Pouget, J., Lefevre, J. P., Valeur, B., Gratton, E., vandeVen, M., Silva, N. D., Jr., Engelborghs, Y., Willaert, K., Sillen, A., Rumbles, G., Phillips, D., Visser, A. J., van Hoek, A., Lakowicz, J. R., Malak, H., Gryczynski, I., Szabo, A. G., Krajcarski, D. T., Tamai, N., and Miura, A. (2007) Fluorescence lifetime standards for time and frequency domain fluorescence spectroscopy. Anal. Chem. 79, 2137-49.

(24) de Mello, J. C., Wittmann, H. F., and Friend, R. H. (1997) An improved experimental determination of external photoluminescence quantum efficiency. Adv. Mater. 9, 230-232.

(25) Case, A., and Stein, R. L. (2003) Mechanistic origins of the substrate selectivity of serine proteases. Biochemistry 42, 3335-48.

(26) Leytus, S. P., Patterson, W. L., and Mangel, W. F. (1983) New class of sensitive and selective fluorogenic substrates for serine proteinases. Amino acid and dipeptide derivatives of rhodamine. Biochem. J. 215, 253-60.

(27) Ramos, S. S., Vilhena, A. F., Santos, L., and Almeida, P. (2000) $\mathrm{H}-1$ and C-13 NMR spectra of commercial rhodamine ester derivatives. Magn. Reson. Chem. 38, 475-478.

(28) Blank, K., De Cremer, G., and Hofkens, J. (2009) Fluorescencebased analysis of enzymes at the single-molecule level. Biotechnol. J. $4,465-479$. 